\title{
Communication Policy of Central Banks The Case of Sri Lanka
}

\author{
Dr. H N Thenuwara ${ }^{1}$
}

\begin{abstract}
Communication policies are important for central banks for two reasons. First, being public institutions it is important to disclose their actions to the general public for maintaining democratic accountability that comes with independence. Second, the policy effectiveness is enhanced if the general public is aware of policies of central banks, and reasons. Realising this, the Central Bank of Sri Lanka is in the process of developing a comprehensive communi-cation policy to portray its accountability and to allow economic agents to make informed judgements about performance of the economy and Central Bank policies. However, there are several issues to be addressed in Sri Lanka before any communication policy takes its intended full effect. (JEL D83, E58)
\end{abstract}

\section{Introduction}

Broadly, there are two types of monetary authorities; central banks and currency boards. Central banks are different from currency boards in terms of objectives and the degree of complexity. The major function of currency boards is to issue currency backed by 100 per cent of reserve assets and through it to maintain the external value of domestic currency, and this sole objective is clearly understood and stated. Many central banks, on the contrary, often have multiple objectives, and are different from each other in terms of the number and nature of these objectives.

According to Brunner (1981), central banking has been traditionally surrounded by a peculiar and protective political mystique. The mystique has thrived on an impression that central banking is an esoteric art. The esoteric nature of the art is moreover revealed by an inherent impossibility to articulate

1/ The author is the Director of Economic Research of Central Bank of Sri Lanka. The author wishes to acknowledge the valuable comments made by Deshamanya Sunil Mendis, Former Governor, Central Bank of Sri Lanka, Miss Kumudinee Saravanamuttu and Mrs. C.K. Nanayakkara. 
its insights in explicit and intelligible words and sentences. However, with the development in markets and market forces, objectives of central banks could not be met solely though central bank actions, and a fair degree of cooperation was required from market participants. This paved the way for the demystifying process of central banks. The process was intensified with the failure of some of the central banks in achieving the most important objective of maintaining price stability, and facing serious crises while attempting to attain other objectives, especially, maintain the international value of their currencies.

The failure in simultaneously realising multiple objectives has prompted several central banks to adopt a single objective. With the introduction of inflation targeting as the single overriding objective by the Reserve Bank of New Zealand in 1990, a remarkable change has occurred regarding the central banks' choice of objectives, targets, instruments, decision making procedures, implementation procedures, and communication. Inflation targeting central banks have been accorded greater independence and accountability. Thus, such central banks are required communicate their policies partly to fulfil their accountability, and partly to ensure that economic agents formulate expectations in line with the desired direction of central bank policies.

The nature of communication becomes increasingly complex with the complexity of central bank objectives, and the way policies are conducted. As illustrated in Blinder et al (2001), the complexity of communication increases with the multiplicity of objectives of central banks (Figure 1).

\section{Figure 1 - Policy Regimes and the Nature of Communication}

\begin{tabular}{|c|c|c|c|c|c|}
\hline $\begin{array}{l}\text { Rule-based } \\
\text { Regime }\end{array}$ & & & & \multicolumn{2}{|c|}{$\begin{array}{c}\text { Discretion-based } \\
\text { Regime }\end{array}$} \\
\hline Currency & \multicolumn{2}{|c|}{ Exchange Rate } & \multicolumn{2}{|c|}{ Inflation Targeting } & Multiple \\
\hline Boards & Hard peg & $\begin{array}{l}\text { Crawling } \\
\text { Peg }\end{array}$ & Point & Range & Objectives \\
\hline Argentina & China & Hungary & Sweden & Australia & Japan \\
\hline Estonia & Denmark & Poland & UK & New Zealar & USA \\
\hline Hong Kong & & & & Euro Area & $\begin{array}{l}\text { SAARC } \\
\text { central } \\
\text { banks }\end{array}$ \\
\hline Simple Com & hunication & & & \multicolumn{2}{|c|}{ Complex Communication } \\
\hline
\end{tabular}


Central banks in South Asia still continue with multiple objectives due to a large number of economic and political realities, although this has made communication by those banks complex. The development objective of a central bank in South Asia cannot be easily dropped. Ensuring the external value of domestic currency remains a sensitive concern even after many central banks have floated their currencies. In the case of Sri Lanka, the hiving off of many activities inherited by central banks, that are not core central banking activities such as public debt management, management of the Employees Provident Fund, and to a certain extent, supervision activities have to be done gradually, and the process has already been started. In addition to these issues, the transition to an inflation targeting framework has been hindered due to a range of issues such as different views on available measures of accepted price indices and core inflation, insufficient improvements in the policy transmission mechanism and some of the fiscal sector concerns (Jayamaha et al 2001/2).

\section{International Initiatives in Promoting Communication}

International financial agencies have been taking steps to improve communication and transparency in relation to the conduct of economic policies by central banks and other authorities. The need for increased transparency has emerged mainly due to three reasons.

i. Financial markets, especially in developed economies, have increasingly felt that central bank actions are affecting their performance, which prompted markets to demand for accurate and timely information from central banks and other relevant authorities. On the other hand, central banks have also realised that increased communication and transparency help reduce undue volatility in financial markets.

ii. High inflation scenarios in many countries in the 1980 s, prompted central banks to focus more on maintaining price stability. Following the initiative by the Reserve Bank of New Zealand, there has been an increasing tendency for central banks to adopt inflation targeting as the framework for monetary policy, which requires greater independence as well as a high degree of transparency.

iii. It has been recognised that the damage caused by the Asian Crisis in 1997, particularly the contagious effect of the crisis could have been minimised if there were higher transparency and good communication policies. 
As a result of the developments highlighted above, international institutions, especially, the International Monetary Fund (IMF), the World Bank and the Bank of International Settlements (BIS) have designed codes and standards of transparency practices for monetary and financial policies, in cooperation with appropriate institutions, with a view to strengthen the architecture of the international monetary and financial system.

Under Reports on the Observance of Standards and Codes (ROSCs), one such initiative to improve transparency, the IMF has recognized 12 areas and associated standards as useful for the operational work of the IMF and the World Bank. These comprise data dissemination; accounting; auditing; anti-money laundering and countering the financing of terrorism; banking supervision; corporate governance; fiscal transparency; insolvency and creditor rights; insurance supervision; monetary and financial policy transparency; payments systems; and securities regulation. The reports covering these areas and standards are used to facilitate the institutions' policy discussions with national authorities and with the private sector.

To strengthen the availability of data for economic analysis, the IMF has developed two data dissemination standards namely the General Data Dissemination System (GDDS) and Special Data Dissemination Standard (SDDS). The purpose was to set up a common platform to disseminate data on a number of key macroeconomic variables in a homogenous way by different countries. The SDDS requires provision of data on key economic aggregates in the four sectors, namely, the real sector, fiscal sector, financial sector and external sector. The GDDS is a lower tier in disseminating similar data categories, which is less demanding than the SDDS. The GDDS is mainly for countries that recognize the importance of providing high quality data, yet whose data preparation and dissemination systems are still in the process of being developed and hence, there are deficiencies in the data. The GDDS also requires publishing data on the same four dimensions mentioned above. Sri Lanka is a participatory country to GDDS and is planning to subscribe to SDDS.

The IMF, working together with the BIS, and in consultation with a representative group of central banks, financial agencies, other relevant international and regional organizations, and selected academic experts, has developed a 'Code of Good Practices on Transparency in Monetary and Financial Policies' as well as the 'Code of Good Practices in Fiscal Transparency'.

The 'Code of Good Practices on Transparency in Monetary and Financial Policies' identifies desirable transparency practices for central banks in their conduct of monetary policy and for central banks and other financial agencies in their conduct of financial policies. The transparency practices listed in the 
Code concentrate on a series of issues; (1) clarity of roles, responsibilities and objectives of central banks and financial agencies; (2) the processes for formulating and reporting of monetary policy decisions by the central bank and of financial policies by financial agencies; (3) public availability of information on monetary and financial policies; and (4) accountability and assurances of integrity by the central bank and financial agencies. The 'Code of Good Practices in Fiscal Transparency' focuses on similar issues with regard to fiscal policy formulation.

\section{Nature of Communication Policy}

Communication, by definition, implies choice - what to say and what not to say. Traditionally, central banks all over the world chose not to say much about their activities, because they thought that maintaining secrecy was necessary for the fulfilment of their tasks and the attaining their objectives (Issing, 2005). As economies became more liberal and markets became fundamental forces in changing economic events, central banks had to share their thoughts with the markets, for attaining their objectives. The new thinking now accepts that clear communications by central banks make their policies more effective and communication plays a significant role in fulfilment of transparency of central banks.

The main component of the communications policy is the content of communications. Other important components are the way of communication and modes of communication. The content should encompass what it is trying to accomplish with regard to the objectives of a central bank and the way of achieving the objectives. This entails communicating on the objectives of policies, methods of policy formulation, decisions and views on future developments. In addition, the public should be made aware of the complexities of the central bank's tasks and that the policy environment is uncertain and constantly changing, specially in an environment where there is uncertainty about prevailing and future economic conditions, the nature and extent of economic shocks and the market expectations process. Communication is also a key tool in portraying the governance, transparency and accountability of a central bank

Characteristics of effective communications as outlined in many studies, and as experienced by the CBSL are as follows (Saravanamuttu 2005).

i. Clarity and Simplicity - Communications should be clear and simple to ensure that the target audience easily understands the communication and to avoid misinterpretation. 
ii. Transparency and Credibility - Communications should be transparent and credible in order to increase their effectiveness. In this regard, information on policy decisions should always be accompanied by the rationale for the particular decision. Matching deeds with words is important to achieve credibility.

iii. Adequacy and Comprehensiveness - Communications should provide sufficient information to enable users to take informed decisions.

iv. Accuracy and Reliability - Information contained in the communications should be accurate and reliable. The quality of information disseminated is more important than the quantity.

v. Timeliness - Communications should be disseminated at appropriate times to be of use to target groups and the public. Communications should strive to be forward looking.

vi. Accessibility and Outreach - The target groups and the public should have easy access to information.

Objectives of communication policy range from providing guidelines to the staff involved in communication and ensuring the effectiveness of central bank policies, while meeting democratic accountability. Some of these objectives are as follows (Saravanamuttu 2005):

To raise awareness among staff of the importance of organized and coordinated communications for the achievement of central bank objectives.

i. To assist the staff to present the central bank and its activities in a unanimous manner and to project the distinctive features of its identity as a professional and accountable institution.

ii. To raise public understanding on how central bank policies and financial sector regulations works and for acceptance of the role of the central bank.

iii. To focus external and internal communications so that it effectively and efficiently contributes to the fulfilment of the central bank objectives.

Central banks use a variety of methods to communicate to markets and the public. With the advent of information technology applications central banks could reach a wide cross section of the public easily and simultaneously. Central banks use press conferences and other means such as public lectures, and periodic publications to reach the public. 


\section{Evolving Communication Policy and Strategy of the Central Bank of Sri Lanka}

The main objective of the evolving communication policy of the CBSL is to provide information on economic developments both in relation to banking and finance as well as other socio-economic aspects, with a high level of accuracy and integrity to a wider audience so that economic agents could make informed decisions. An open and coherent communication strategy helps central banks in several ways. First and foremost, it enhances the effectiveness of monetary policy. A clear communication policy also helps to reduce risks and volatility in financial markets, which is another key concern of many central banks. To achieve the objectives of the Central Bank, transparency, accountability and credibility in its policies and working methods will be helpful.

An important feature in the communication policy of the CBSL is the procedure adopted in communication. As the authority that makes policy decisions, the Monetary Board is responsible for the overall communication policy. The Board has delegated its authority on communication policy to the Governor and the Deputy Governors. Several officers have also been authorised to disseminate information that are of routine nature. However, the accountability of the communication lies with the Monetary Board.

The Monetary Law Act of 1949 (Government of Sri Lanka , 1949) establishing the Central Bank of Sri Lanka (CBSL) requires the Monetary Board of the CBSL to disseminate information on Central Bank assets and liabilities monthly, an annual report containing details of the condition of the Central Bank, review of policies and measures adopted by the Monetary Board, and an analysis of the economic and financial circumstances which prompted those policies and measures. The Law further requires the Monetary Board to include in the annual report several series of data on the monthly movements of the money supply, the monthly movements of purchases and sales of exchange and of the international reserve of the Bank, the annual balance of payments of Sri Lanka, the monthly indices of wages, of the cost of living, and of import and export prices, the monthly movement of exports and imports, the monthly movement of the accounts of the Central Bank and, in consolidated form, of the commercial banks, as well as the principal data on government receipts and expenditures and on the state of the public debt.

In view of the structural changes and developments in the economy particularly following the liberalisation of the economy in 1977, there has been a growing demand for timely and comprehensive information. This has been augmented in the aftermath of the Asian financial crises, especially for greater transparency of financial policies and wider spectrum of data. 
The need for a well-articulated communication policy was further intensified with the modernisation of the CBSL (Central Bank, 2001). The challenges brought about by ever increasing complexities in financial systems and new thinking on economic policy and the role of central banks in a changing world have prompted the CBSL embarked on a modernisation programme. The Monetary Law Act under which the CBSL has been established was amended in 2002 to move away from multiple objectives to focus on two core objectives, $(a)$ economic and price stability and $(b)$ financial system stability, with a view to encouraging and promoting the development of the productive resources of Sri Lanka. Achieving the objectives was further facilitated by establishing several committees in the CBSL.

Since monetary policy is the means by which the CBSL attempts to attain the objective of economic and price stability, monetary policy communication has become one of the major components of the overall communication policy. To strengthen the institutional arrangement for the determination of the monetary policy decision-making process and to improve transparency and accountability, the CBSL established the Monetary Policy Committee (MPC) in 2000. Furthermore, to enhance the effectiveness of monetary policy operations, the CBSL moved to a more market-oriented open market operation system. With the shift to this system in March 2003, the CBSL commenced reviewing the monetary policy stance on a monthly basis and issuing press releases on the monetary policy stance, with explanatory notes providing more information to the market on monetary and other economic developments. An advance release calendar of monetary policy reviews is also published giving the dates on which the monetary policy is reviewed. In addition, the overall monetary policy framework and monetary policy targets are posted on the Bank's website. ${ }^{2}$

Since maintaining financial stability is the second objective, measures have also been taken to improve the financial system stability. The Financial Stability Committee (FSC) was established in 2002. One of the main tasks of the FSC is to prepare and publish a Financial Stability Report (FSR) assessing the risks and vulnerabilities leading to financial system instabilities of a significant scale in the country (Central Bank, 2005).

To make its financial statements internationally comparable and adopt disclosure and accounting policies in line with international best practices, the CBSL has adopted International Accounting Standards (IAS) as the accounting framework for producing its financial statements. The Bank was able to achieve substantial IAS compliance in 2001, 2002, and 2003, and it intends to achieve the full compliance in 2004. A more detailed description of financial statements prepared for the year 2003 on the basis of International

2/ www.centralbanklanka.org 
Financial Reporting Standards (IFRS) was published as a separate document. The CBSL also publishes a monthly general balance sheet, giving information on the volume and composition of foreign assets, domestic assets and foreign liabilities and domestic liabilities.

A large audience consisting of both domestic and foreign constituencies could be the recipients of information disseminated by the CBSL. In general, the domestic audience includes government officials, politicians, financial market participants, the academic and other professionals and the general public. Foreign constituents include multilateral financial institutions and the donor community including the International Monetary Fund, the World Bank, the Asian Development Bank and other institutions such as regional organisations and international research institutions. As the level of expertise and the required details of various constituencies are diverse, the CBSL always tries to maintain clarity and provide the necessary details to strike a balance in catering to these different needs.

The CBSL has always made a conscious attempt at maintaining integrity and ethical standards in communication. The Bank always issues its major publications, and press releases and conduct press conferences in all three languages used in Sri Lanka, viz., Sinhala, Tamil and English. Information is always released simultaneously to all concerned parties.

Although there could be restraints in disclosing confidential information and financial policy related issues that could destabilise markets, the goal of the CBSL is to provide accurate and timely information. When a clarification is sought or when news appears in media questioning policies or activities, the Bank responds promptly.

Another important factor in respect of the Bank's communication policy is the procedure adopted in communication. As the Monetary Board of the CBSL is the authority that makes policy decisions, the Monetary Board is responsible for overall communication policy. The Board has delegated its authority to communicate on policy matters to the Governor and the Deputy Governors. However, other authorised officers would disseminate information of routine nature.

Sri Lanka has participated in many of these initiatives undertaken by international financial institutions to assess the quality of the dissemination of information and the level of transparency. For instance, an evaluation of Sri Lanka's position against these codes was made under the Financial Sector Assessment Program (FSAP) and for the Report on Observance of Standards and Codes (ROSC), which are the frameworks for enhanced financial system surveillance developed by the IMF and the World Bank. Sri Lanka is one of the first countries to participate in GDDS. The graduation to SDDS is only 
two steps away, the compilation of international investment position and the reduction of lag in some of the variables, which are being speedily resolved.

To enhance the awareness among participants in the payment systems work in Sri Lanka, the CBSL jointly with Committee on Payment and Settlement Systems (CPSS) of the central banks of G-10 countries has prepared the Red Book, 'Payment Systems in Sri Lanka' which was published by the BIS in 2004 (Central Bank 2004). Since the inception of the CPSS in 1990, BIS has published Red Books for 15 countries and Sri Lanka became the sixteenth country in the world to publish its Red Book. In the Asian region, Sri Lanka was the third to publish this report, after Singapore and Korea.

The CBSL has published an advance release calendar of all information, press releases and publications (Table 1 and 2). Most important communication made to the general public is the monthly press release on the changes in monetary policy stance. In addition, The CBSL issues a number of publications in all three languages. The Annual Report of the CBSL provides a detailed coverage of macroeconomic developments and of the operational activities of the Central Bank. The Bank also issues the Recent Economic Developments and Prospects covering the developments during the first half of each year and future prospects. The Financial Stability Review provides an assessment of the banking and financial sector. In addition, the CBSL publishes several monthly and ad-hoc reports covering economic developments to meet requirements of different audiences. Many of these publications are available in all three languages. These are complemented with periodicals, published in all three languages containing articles on economic and finance/banking and

Table 1 - List of Major Regular Publications by the Central Bank of Sri Lanka

\begin{tabular}{|lll|}
\hline Publication & Frequency & Language \\
\hline 1. Economic Indicators & Weekly, & Sinhala, Tamil, English \\
& Monthly & \\
2. Monthly Bulletin & Monthly & Sinhala, Tamil, English \\
3. Satahana & Quarterly & Sinhala \\
4. News Survey & Quarterly & English \\
5. Kurippedu & Quarterly & Tamil \\
6. Financial Stability Review & Bi-annaully & English \\
7. Staff Studies & Bi-annaully & English \\
8. Annual Report & Annually & Sinhala, Tamil, English \\
9. Recent Economic Developments & Annually & Sinhala, Tamil, English \\
10. Economic and Social Statistics & Annually & English, Sinhala \\
11. Consumer Finance Survey Report & Once in & English \\
& 5 years & \\
\hline
\end{tabular}


Table 2 - Advance Release Calendar

\begin{tabular}{|ll|}
\hline Information & Date \\
\hline 1. Sri Lanka Inter Bank Offered Rates & Daily at $10 \mathrm{am}$ \\
2. Open Market Operations Auction Results & Daily at $11.30 \mathrm{am}$ \\
3. Exchange Rates & Daily at 12 noon \\
4. Call Market Rates & Daily at $4 \mathrm{pm}$ \\
5. Secondary Market Rates of & Daily at $4 \mathrm{pm}$ \\
$\quad$ Government Securities & \\
6. Government Securities Auction Results & As pre announced \\
7. Consumer Prices & Last day of Month at 3 pm \\
8. External Trade Performance & Second week of Month \\
9. Monetary Policy Statements - 2005 & January 15 \\
& February 16 \\
& March 16 \\
& April 12 \\
& May 13 \\
& June 15 \\
& July 15 \\
& August 17 \\
& September 16 \\
10. Estimates of Gross Domestic Product & October 14 \\
& November 16 \\
& December 16 \\
& Last Day of Each Quarter \\
&
\end{tabular}

other areas of current economic interest. The Bank also publishes research studies and articles in its journal of Staff Studies.

With a view to providing information on monetary operations and other key macroeconomic aggregates on a regular basis, the CBSL issues regular updates through press releases as new data become available. At present, regular press releases are issued on monetary policy, price developments, external sector developments and economic growth. In addition, the Bank organises press conferences on matters of public interest as well as to clarify specific issues and senior officials of the Bank conduct these.

Bank holds regular discussions with the financial sector market participants, where major changes to policy are discussed to obtain a feedback before implementing. The Bank also holds monthly meetings with the Chief Executive Officers of banking institutions where important policy changes are discussed. In addition, the CBSL holds regular meetings with primary dealers in government securities, finance companies and foreign exchange dealers. 
On specific issues, the CBSL conducts several public awareness programmes in the form of paper notices, special publications and meetings to educate the general public. The Bank undertook a special programme to educate the pubic on unauthorised institutions soliciting deposits from the public. In this regard, the public was mainly informed of the following:

- The public have to bear the risks involved in their transactions with financial institutions

- Regulation and supervision does not involve a guarantee of deposits or any other transaction or the safety of any institution.

- There may be institutions accepting deposits from the public without legal permission and risks involved in those institutions would be greater since they are not regulated or supervised by the CBSL or any other authority.

During 2004, attention of the CBSL was drawn to pyramid schemes that were operating in the country. In the absence of necessary legislation against such schemes, which pose a threat to the country's financial stability, the CBSL undertook an awareness programme among the members of the public on the risks and dangers associated with pyramid schemes.

The CBSL conducts awareness programs for the benefit of students and teachers on issues relating to banking, finance and economics. Several articles on these areas are included, for example in the CBSL regular publications such as 'Kauluwa', 'Satahana' and 'News Survey'. The CBSL issues updates on key macroeconomic aggregates weekly and monthly.

In addition, the dissemination of information through electronic means is now becoming increasingly important as it provides instantaneous access not only to domestic audience but also to a wider global audience. The CBSL maintains a website and makes regular updates with latest information. The CBSL also participates in exhibitions, conducts public seminars, and operates a currency museum and a library in its effort to disseminate information to a wider audience.

The CBSL has recognised that internal communication is also a major factor in reinforcing its organisational identity and command. The staff of the CBSL should have the opportunity to be well informed so that information about the bank will be released externally in a correct and uniform manner. Internal communications are made through both electronic and paper based publications. The intranet is the most commonly used mode. It is supplemented by a monthly in-house magazine. In addition all communications made to the general public are circulated among all members of the staff. 


\section{Limitations of Communication - The Sri Lanka's Perspective}

Communication is a complex task in Sri Lanka due to several important issues that are being resolved. The CBSL operates with two objectives, economic and price stability, and financial system stability, while being mindful of the exchange rate behaviour. Those objectives are not articulated in terms of explicit targets. This has become even more complicated due to diverse views on crucial measures such as inflation. Furthermore, the efficacy of transmission mechanism of monetary policy has to be improved further. In addition, some of the large fiscal operations could pose challenges to monetary operations. Thus, there exists room for diverse interpretations of central bank communiqués.

In the past, there are occasions when media has misinterpreted and miscommunicated central bank information, causing wide fluctuations in market behaviour. The diversity of recipients of communications of the CBSL, their ability to decipher those communications, and the thin financial markets have partly contributed to those misinterpretations. Such misinterpretations are also due to the insufficient developments in economic journalism in the country. The CBSL has conducted several programs to educate the media personnel on important economic and financial issues.

The communications on financial stability is also tricky. Often, prompt and factual communications on any adverse developments in the financial sector could lead to undesirable and adverse outcomes, especially in view of self-fulfilling nature of economic prophecies. Thus, communications on financial system stability have to be made delicately. However, the CBSL has been insisting on financial institutions to disclose their information on a wide spectrum of issues such as performance, interest rates, financial charges and other prudential indicators, while making available to the public a set of important indicators as well as a biannual report on financial stability.

In view of those concerns, the CBSL has to continue to address a wide array of issues to further ensure the efficacy of its communication. 


\section{References}

Brunner, Karl, (2001), “The Art of Central Banking” in Hermann Göppl and Rudolf Henn, eds., Geld, Banken und Versicherungen. Volume 1. Königstein.

Blinder, A., Goodhart C., Hildebrand P., Lipton D., and Wyplosz C., (2001), "How do Central Banks Talk?", Geneva Report on the World Economy No. 3, CEPR.

Central Bank of Sri Lanka, (2001), "Modernisation of the Central Bank, Box II-1", Annual Report, Central Bank of Sri Lanka, Colombo.

Central Bank of Sri Lanka, (2004), "Red Book on Payment and Settlement Systems in Sri Lank", Central Bank of Sri Lanka, Colombo.

Central Bank of Sri Lanka, (2005), Financial Stability Report, Central Bank of Sri Lanka, Colombo.

Government of Sri Lanka, (1949), Monetary Law Act, Sri Lanka.

International Monetary Fund, (2005), Reports on the Observance of Standards and Codes (ROSCs), www.imf.org.

International Monetary Fund, (2005), Dissemination Standards Bulletin Board, www.imf.org.

International Monetary Fund, (2005), Code of Good Practices on Transparency in Monetary and Financial Policies, www.imf.org.

International Monetary Fund, (2005), Code of Good Practices in Fiscal Transparency, www.imf.org.

Issing, Otmar, (2005), "Communication, Transparency, Accountability: Monetary Policy in the Twenty-First Century", Federal Reserve Bank of St. Louis Review, Vol 87 (2, Part 1), pp 65-83.

Jayamaha R., Thenuwara H.N., Weerasinghe P.N., Silva B.D.W.A., Karunathilake C.P.A., Ratnasiri H.P.G.S., Chandrawansa P.H.O., Perera R.A., and Gunaratne S., (2001-2002), "Feasibility of Inflation Targeting in Sri Lanka", Staff Studies Vols. 31 \& 32, Central Bank of Sri Lanka.

Saravanamuttu, K., (2005), “Communications Policy and Strategy”, mimeo, Central Bank of Sri Lanka. 